\title{
THE EFFECT OF GAMMA IRRADIATION ON HDPE/HA COMPOSITE AS CANDIDATE MATERIAL DENTAL IMPLANT
}

\author{
Pormauli Gultom*1 | Sigit T. Wicaksono $^{1}$ | Agung Purniawan ${ }^{1}$ | Sudirman Sudirman ${ }^{2}$ | Sulistioso \\ Giat Sukaryo $^{2}$
}

\footnotetext{
${ }^{1}$ Dept. of Material and Metallurgy, Institut Teknologi Sepuluh Nopember, Surabaya, Indonesia

${ }^{2}$ The Center for Science and Technology of Advanced Materials (PSTBM), National

Nuclear Energy Agency, Serpong, Indonesia
}

\section{Correspondence}

*Pormauli Gultom, Dept. of Material and Metallurgy, Institut Teknologi Sepuluh Nopember, Surabaya, Indonesia. Email: porma811@gmail.com

\section{Present Address}

Gedung Teknik Material, Kampus ITS

Sukolilo, Surabaya 60111, Indonesia

\begin{abstract}
Hydroxyapatite (HA) $\mathrm{Ca}_{10}\left(\mathrm{PO}_{4}\right)_{6}(\mathrm{OH})_{2}$ is the main component of calcium phosphate-based bone, which is most widely used in biomaterial applications because it has non-toxic and biocompatible properties. But if used alone, HA does not have excellent mechanical strength and is not resistant to pressure. High-Density Polyethylene (HDPE) is a high density of synthetic polymers, and hydroxyapatite (HA) is a vital bone component. Composites of them will make synthetic bones, with HDPE as matrix and HA as fillers. HDPE/HA composites with a composition variation of $0 \%, 5 \%, 10 \% \mathrm{HA}$ were compacted and heated at $180^{\circ} \mathrm{C}$ for 90 minutes, and then irradiated at a dose of $60 \mathrm{kGy}$. The effect of adding HA composition and gamma irradiation was observed by hardness testing and characterized using XRD and FTIR. The results showed that the addition of HA increased the hardness of HDPE. From the XRD and FTIR analysis, there was no change in the composite phase after irradiation.
\end{abstract}

\section{KEYWORDS:}

Dental Implant, HDPE, Hydroxyapatite, Gamma Irradiation

\section{1 | INTRODUCTION}

Progress in the field of Implantology in dentistry has undergone a variety of advances quite rapidly. Problems that have been difficult to work with to obtain dentures in their jaws, especially those who lose half or all of their teeth, can use dental implants. Dental implants are one of the ways to replace missing teeth and are expected to achieve the ideal function of the stirring, aesthetic, and comfort. Dental implants are dentures (from synthetic materials) attached to the patient's mouth through surgical action so that dentures are embedded into the jaw bone and can stand on its own without disturbing other healthy teeth. The principle of dental implants similar to different types of artificial teeth is to improve the function of the reproduction. The 
difference is that in other types of false teeth, it generally only replaces the tooth crown, while the implant consists of two parts that the infrastructure that is embedded in the bones and serves to replace the root and superstructure of its function. An ideal implant material must meet several requirements: biocompatible, have adequate strength and hardness, resistant to corrosion, resistant to wear, resistant to fracture, implant design principles must conform to physical properties of the implant material.

Dental implants can be made from metallic, ceramic, or polymer materials. Titanium has been widely used for biomedical applications under the conditions of the load because of its biocompatible and low-density properties coupled with a right balance of mechanical and rust-resistant nature ${ }^{102]}$. However, titanium is a bioinert material. For example, the interface between titanium and the original bone (host bone) is a simple bonding (interlocking), which can lead to loosening of the implant and can eventually lead to implantation failure ${ }^{3}$. This material has been successfully used as a replacement for bones and reconstruction in the field of orthopedic, and teeth. However, one of the main barriers to clinical use as a loaded implant is poor mechanical properties ${ }^{[4]}$. In general, composite materials are composed of two main components, matrix (binder) and filler (filler material). The matrix in composite structure can be derived from polymer, metal, and ceramic materials. Matrix serves to bind the fibers into one composite structure. Filler materials are used in the manufacture of composites, usually fiber or powder. The use of fiber in dentistry has several functions, such as increasing strength and stiffness, improving the resistance of the material to fractures or fractures, as well as lowering the depreciation (shrinkage) ${ }^{[5}$. Polymer Matrix Composite (PMC) is the most commonly used matrix in composite materials because it has properties that are more resistant to corrosion and lighter. The polymer matrix is divided into two, i.e. thermoset and thermoplastics. The difference is that thermoset polymer is not recyclable, while thermoplastics can be recycled so that it is more widely used lately. The types of thermoplastics commonly used are polypropylene (PP), Polystyrene (PS), polyethylene (PE), and others.

A mixture of biocomposite should be able to fulfill the physical properties and mechanical properties that have been determined. There are many potential ingredients to be used as a mixture of biocomposites. One of the ingredients that can be used is hydroxyapatite (HA). HA has osteoconductive properties and osseointegration (the ability of materials to blend with bones). Nevertheless, HA has a weakness that unable to withstand mechanical loads. Additional materials are expected to improve the weakness of the HA. Materials that can be added to be able to increase the mechanical strength of the biocomposite is HDPE (High-Density Polyethylene). HDPE is a type of polymer with high density, is flexible, impact-resistant, low temperature resistant, even resistant to the temperature of frozen water potential as a candidate matrix on the manufacture of composite bone replacement. Besides, HDPE is resistant to chemicals, and its price is economical. The requirements for dental implants are not much different from the condition of the ingredient for bone implants. The properties of the implant material can be reviewed from the nature of the hardness, structure, thermal properties, and function groups found in the implant material.

The researchers have tried to develop a model of the rotary kiln that considers a heat transfer phenomenon and the kinetic reaction of clinker formation along with the kiln. The first model has studied by Spang. Spang has developed a dynamic model with a simple flame model as a heat supply of the kiln. This result shows that the profile of temperature and the composition along the kiln obtained is matched with the actual profile of kiln as qualitatively. Still, as quantitatively, this model is not accurate enough, especially the wall temperature ${ }^{[5]}$. In 1989, Bar et al. have studied the model of rotary kiln. Their mathematical model developed has been compared with the pilot plant of kiln ${ }^{4[5]}$. Then, Bar's model has been developed by Li et al., especially for evaluate the heat transfer coefficient of the covered wall and exposed bed in the rotary kiln. Both Bar's model and Li's model only focus on the heat transfer phenomena along with the kiln and negligible the chemical reactions occurred ${ }^{[5]}$. In 2006 , Mujumdar and Ranade developed a one-dimensional model 1D of rotary kiln. Their result shows that the model is entirely accurate to predict the composition of the outlet clinker. But the maximum bed temperature achieved is under the range of actual temperature [5]. In 2017, Csernyei and Straatman developed a numerical model that considers heat transfer on the outside wall of the kiln. This approach is due to the installation of a cooling fan on the outside wall. Due to this model uses a different model of clinker formation with Mujumdar's model, Csernyei's model only success in improving the bed temperature profile. Still, the composition model has a significant error ${ }^{[5]}$.

This study aims to obtain the one-dimensional mathematical model with an accurate model to show the profile temperature and composition along with the kiln. This study will combine the model developed by Mujumdar as a clinker formation model and Csernyei as a heat transfer model. 


\section{2 | MATERIAL AND METHOD}

This study used 10-20 nm particle size HA material from the synthesis of fish scales and obtained from PAIR BATAN Pasar Jumat, South Jakarta. The HDPE material used is a pellet with a density of $0.954 \mathrm{~g} / \mathrm{cm} 3$ obtained from BATAN Serpong. HDPE and HA pellets were taken using a spatula, and measure their mass using an analytical balance of the Electronic BOSCH SAE 200 brand to make composites with a composition variation of $0 \%, 5 \%$, and $10 \% \mathrm{HA}$ and then with a temperature of furnace 1800C for 90 minutes. The results of this process are HDPE/HA composite pellets.

\subsection{Composite Irradiation with Gamma Rays}

Gamma rays from radioisotope Co60 irradiated the HDPE/HA composite sample. Irradiation was carried out using an Irradiator Gamma Cell 220 (IGC 220) with a radiation dose of 0kGy and $60 \mathrm{kGy}$ with a dose rate of $7.5 \mathrm{kGy} / \mathrm{hour}$.

\section{2 | Hardness Test}

HDPE/HA composite samples were measured using calipers with a diameter of more than or equal to $3 \mathrm{~mm}$. Furthermore, samples were placed on the Shore Durometer D instrument. Measurements were made at three different points in the sample and then obtained the average value of polymer hardness.

\section{3 | Characterization of X-Ray Diffraction (XRD)}

Composite samples with doses of 0 and $60 \mathrm{kGy}$ of a certain size were attached to the sample in the PAN Analytical XRD brand. Next, the sample is scanning at an angle of $2 \vartheta$ between $10^{\circ}$ to $60^{\circ}$. Crystallinity analysis was carried out using the XRD tool. The tool was used to determine the elemental composition of a material, characterizing the crystal structure, the size of the crystals of nanohydroxyapatite crystals produced ${ }^{[6]}$. The degree of crystallinity is the regularity of the placement of atoms in cell units and crystal lattices. The degree of crystallinity is calculated using the FWHM (Full Width at Half Maximum) parameter.

The crystalline or amorphous fraction is calculated by multiplying FWHM with intensity. FWHM is considered to be half the area of the base and concentration as height. The degree of crystallinity can be determined by the diffractogram of the XRD results based on the peak area using Equation $1{ }^{6}$.

$$
\text { crystallinity }=\frac{\text { areaundercrystallinepeaks }}{\text { Totalareaunderpeaks }} \times 100 \%
$$

\subsection{Characterization of Fourier Transform InfraRed (FTIR)}

Analysis with the FTIR tool is used to know the typical function clusters of HA and PE are generated. The test samples were first formed pellets with a mixture of $\mathrm{KBr}$. A total of $100 \mathrm{mg}$ of $\mathrm{KBr}$ and $2 \mathrm{mg}$ of test samples were pounded until smooth and well blended in the Agate mortar. Test sample measurements are performed on wavelengths between $4000-500 \mathrm{~cm}^{-1}$. The resulting spectra FTIR shows the peaks of the wavenumber from the test sample. The cluster of test sample functions is determined based on the absorption of detected waveforms ${ }^{[7]}$. HA has the content of OH- Groups, CO32- groups, and PO43-groups. These three groups are the main components in the formation of HA.

The results of reading the spectra indicate that the CO32- group is detected at wave number $1459-1416 \mathrm{~cm}^{-1}$. This result is supported by indications of a carbonate group in the sample peaks at a range of wavelengths of $1400-1500 \mathrm{~cm}^{-1}[8]$. The OHgroup content in the sample was detected from the spectra's visual reading between the wavelengths of $3542-3570 \mathrm{~cm}^{-1}$. Peak detected at wavenumbers $3300-3600 \mathrm{~cm}^{-1}$ indicates the presence of a hydroxyl group ${ }^{8}$. The PO43-sample content indicated by visual readings of spectral peaks was identified at wavenumbers 1046-1091 $\mathrm{cm}^{-1}$ and wave number readings $572-603 \mathrm{~cm}^{-1}$. The detection of this phosphate group has similarities with the formation of phosphate complexes at wavenumbers ranging from $1000-1100 \mathrm{~cm}^{-1}[$. 


\section{3 | RESULTS AND DISCUSSION}

\section{1 | Hardness Test Analysis (ASTM D2240)}

Hardness is one of the fundamental properties of the material and has been often used as an indicator of polymer wear resistance ${ }^{[10]}$. Composite HDPE/HA samples carried out hardness testing using the Shore Durometer to see the influence of HA composition and gamma irradiation on the value of the composite hardness of HDPE/HA. The results of the hardness test analysis can be seen in Table 1 and the interpretation in Figure 1

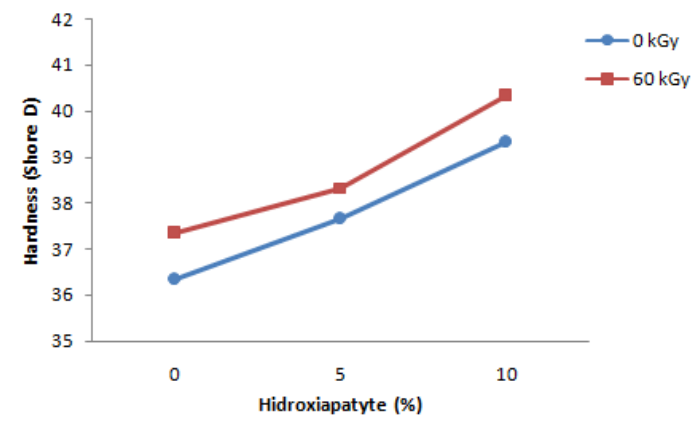

FIGURE 1 Hardness test results (Shore D).

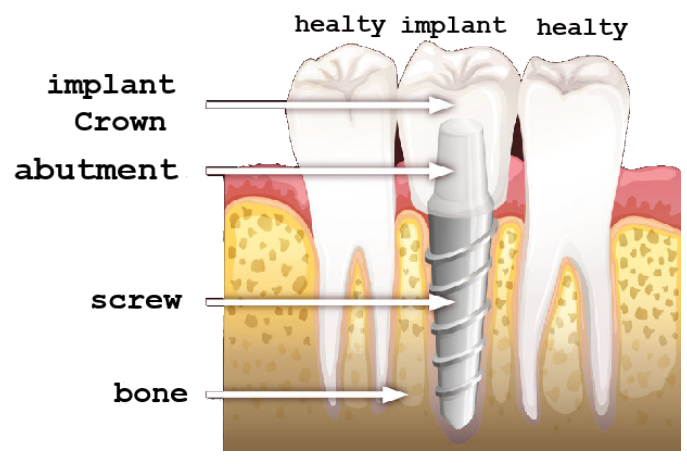

FIGURE 2 Structure of dental implant.

\section{2 | X-Ray Diffraction (XRD) Test Analysis}

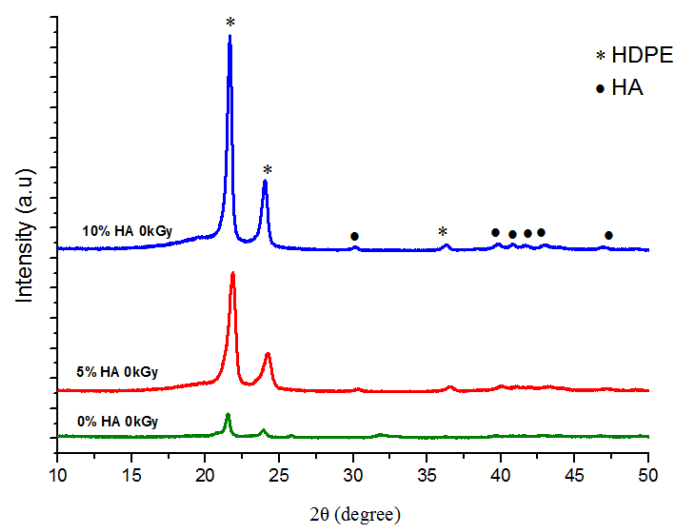

FIGURE 3 Results of 0kGy HDPE/HA composite XRD.

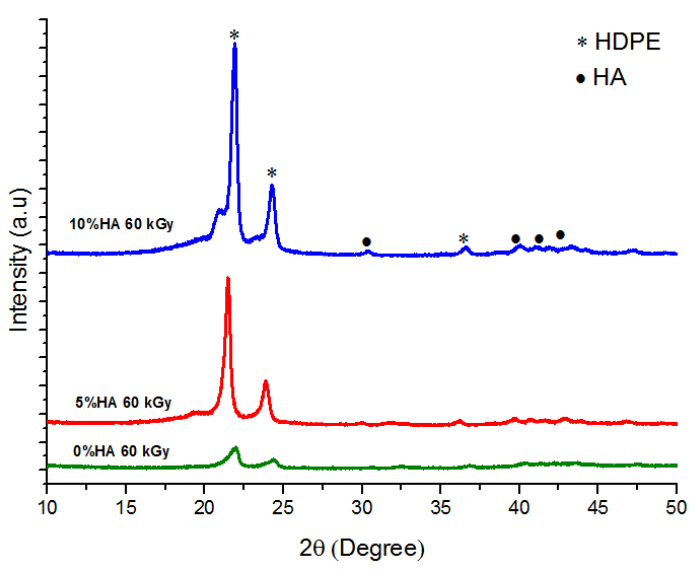

FIGURE 4 Results of 60kGy HDPE/HA composite XRD.

XRD characterization was used to analyze the phase and degree of crystallinity from HDPE/HA composite to the addition of HA composition and gamma irradiation. Based on Figure 3 shows a specific phase for HDPE polymer at an angle of $2 \vartheta=21.80,24,280$, and 36.40. This data is in accordance with the Joint Committee Powder Diffraction Standards (JCPDS) database number 00-054-1982. It is in accordance with the research that the specific HDPE phase on $2 \vartheta=21,440,23,830,2 \vartheta$ $=21.30$ and $23.70,2 \vartheta=26,440$ and $21,390,23,560$, and 36.130 , and $2 \vartheta=21,580,23,920$. 11.14 . The XRD pattern of the HA phase (Figure 3 is at an angle of $2 \vartheta=30,220,36,320,39.910,40,820,41,580,43.030,44.040,47.060,49.110$. This data corresponds to the database JCPDS number 00-001-1008 and also according to the research that the HA phases are specific to 
the positions of $25,980,31,930,49,740$, and 53,260 15 . Therefore, based on the diffractogram pattern in Figure 3 , it appears that the phase position of the HA composition variation does not change. The addition of HA composition variation does not affect the composite phase of HDPE/HA.

Based on Figure 4 shows a specific phase for HDPE polymer at an angle of $2 \vartheta=21,920,24.310$, and 36,620. This Data is in accordance with the Joint Committee Powder Diffraction Standards (JCPDS) database number 00-054-1982. It is in accordance with the research that the specific HDPE phase on $2 \vartheta=21,440,23,830,2 \vartheta=21.30$ and 23.70, $2 \vartheta=26,440$ and 21,390, 23,560, and 36.130 , and $2 \vartheta=21,580,23,920$ [ 811$] 14$. The XRD pattern of the HA phase (Figure 4 is at $2 \vartheta=30.280,40,040,41,900$, $43,290,44,350,47,330,49,440$. This data corresponds to the database JCPDS number 00-001-1008. It is in according to the research that the HA phases are specific to the positions of 25,980, 31,930, 49,740, and 53,260 [15]. Therefore, based on the diffractogram pattern in Figure 3 it appears that the phase position of the HA/HDPE composition variation does not change. The addition of HA composition variation does not affect the composite phase of HDPE/HA.

Table 2 shows a degree increase in crystallinity along with the addition of HA composition. This is due to the apatite has spread in the samples. However, the degree of crystallinity of the composite sample decreases after gamma irradiation. This is because after the composite sample of HDPE/HA is irradiated. The cross bonding occurs, which causes HDPE structure to be semicrystalline or the occurrence of HDPE phase changes from the crystalline phase to the amorphous phase. This is in accordance with [16] that the degree of crystallinity decreases after the gamma irradiation—-decreased degree of crystallinity due to degradation. The process of degradation through oxidation resulted in a radical migration from the crystalline phase to the amorphous surface ${ }^{177}$. The existence of HA fillers, although not interacting chemically with HDPE, however, contributes to the increase in the value of HDPE/HA degree crystallinity because the HA grains will infiltrate between the polymer chains, making the barrier to the polymer chain can move freely. The existence of the HA mixing also improves the biomechanics of HDPE/HA composite samples.

\section{3 | Fourier Transform InfraRed (FTIR) Test Analysis}

FTIR characterization aims to determine the functional groups in HDPE / HA composites formed in gamma radiation's presence. The results of FTIR analysis showed that the composite sample was identified as having a component/group consisting of OHgroups, $\mathrm{CO} 32$ groups - and $\mathrm{PO} 43$ - groups.

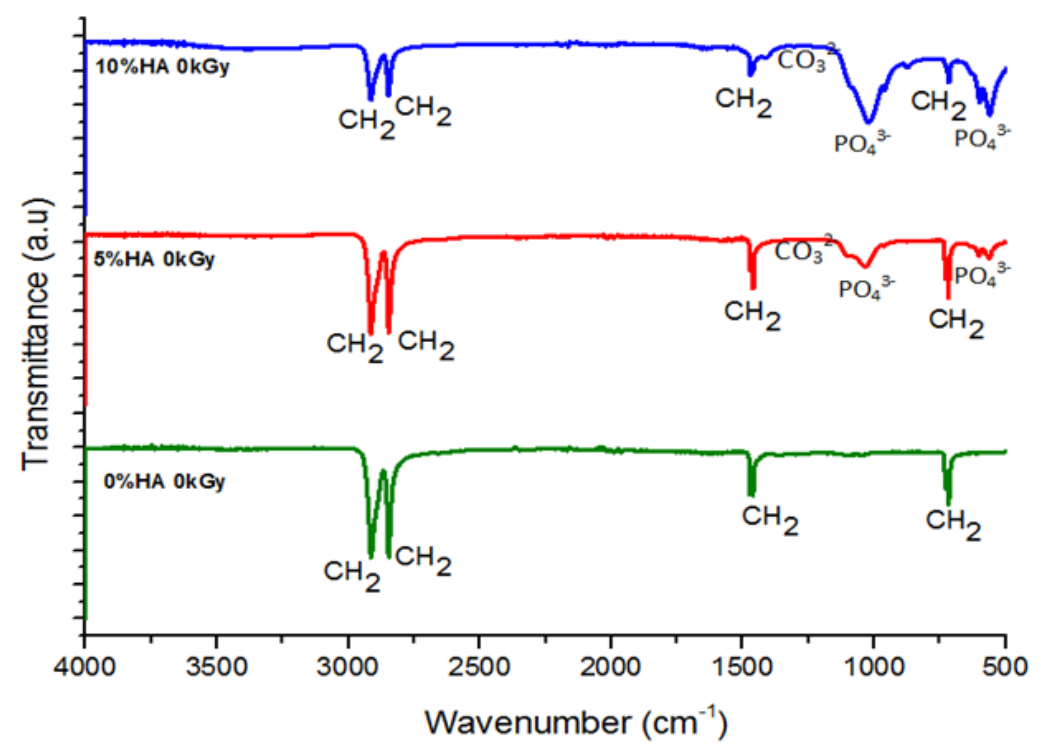

FIGURE 5 Results FTIR characterization HDPE/HA 0kGy. 


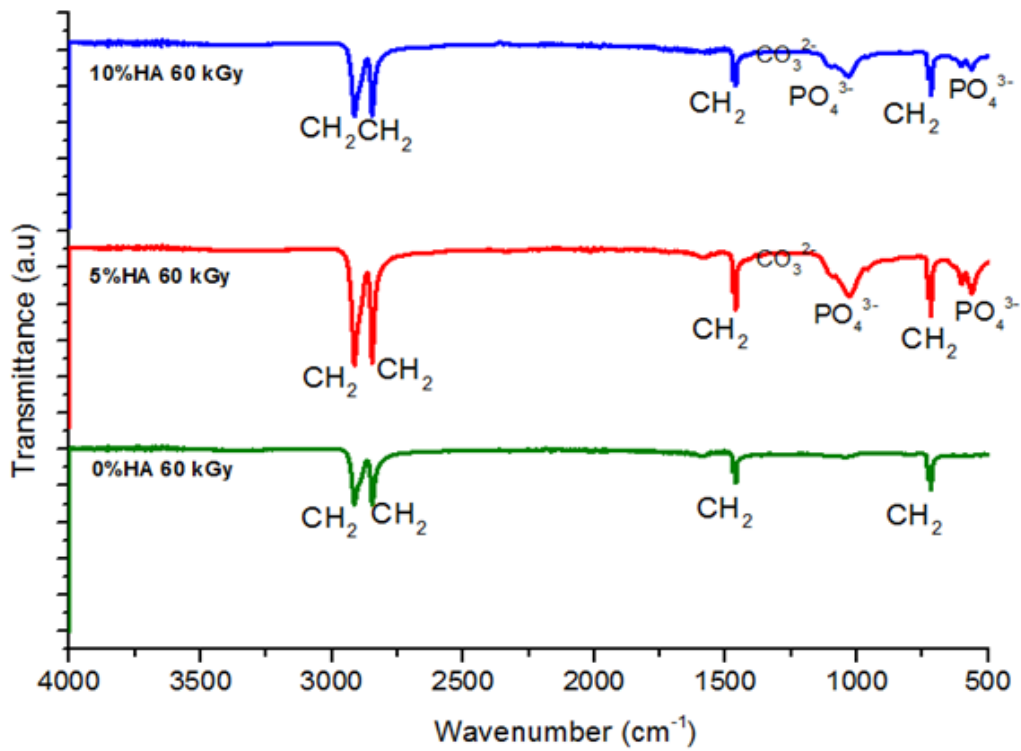

FIGURE 6 Results FTIR characterization HDPE/HA 0kGy.

According to Figure 5 obtained the peak of the polyethylene function group and HA on the number of waves respectively. This is in accordance with the research ${ }^{[18]}$ which states that HDPE has a specific vibration that is on the number of waves 2913.4 $\mathrm{cm}^{-1}, 2846.49 \mathrm{~cm}^{-1}, 2357.73 \mathrm{~cm}^{-1}, 1474.21 \mathrm{~cm}^{-1}, 1367.57 \mathrm{~cm}^{-1}$ and $718.79 \mathrm{~cm}^{-1}$. Further research $2915 \mathrm{~cm}^{-1}, 2850 \mathrm{~cm}^{-1}$, $1467 \mathrm{~cm}^{-1}$, and $720 \mathrm{~cm}^{-1}$ identified the groups function of HDPE in the number of waves $718.79 \mathrm{~cm}^{-1}, 730.33 \mathrm{~cm}^{-1}, 1367.57$ $\mathrm{cm}^{-1}, 1461.72 \mathrm{~cm}^{-1}, 1472.21 \mathrm{~cm}^{-1}, 2357.73 \mathrm{~cm}^{-1}, 2846.49 \mathrm{~cm}^{-1}$ and $2913.46 \mathrm{~cm}^{-1}$ [14]18] The functional group identified in HA are phosphate clusters PO43- on the number of waves $1024 \mathrm{~cm}^{-1}-1092 \mathrm{~cm}^{-1}$, CO32- at a wave number of $1420 \mathrm{~cm}^{-1}$ $-1456 \mathrm{~cm}^{-1}$, and OH- 3700-3600 $\mathrm{cm}^{-1}, 3550-3500 \mathrm{~cm}^{-1}$, and 3000-1700 $\mathrm{cm}^{-1}$ and at ave number of about $3576 \mathrm{~cm}^{-1}$ and $632 \mathrm{~cm}^{-121[22]}$.

According to Figure 6 obtained the peak of the polyethylene function group and HA on the number of waves respectively. This is in accordance with the research which states that HDPE has a specific vibration that is on the number of waves $2913.4 \mathrm{~cm}^{-1}$, $2846.49 \mathrm{~cm}^{-1}, 2357.73 \mathrm{~cm}^{-1}, 1474.21 \mathrm{~cm}^{-1}, 1367.57 \mathrm{~cm}^{-1}$ and $718.79 \mathrm{~cm}^{-1}\left[18\right.$. Further research $2915 \mathrm{~cm}^{-1}, 2850 \mathrm{~cm}^{-1}, 1467$ $\mathrm{cm}^{-1}$, and $720 \mathrm{~cm}^{-1}$ identified the groups function of HDPE in the number of waves $718.79 \mathrm{~cm}^{-1}, 730.33 \mathrm{~cm}^{-1}, 1367.57 \mathrm{~cm}^{-1}$, $1461.72 \mathrm{~cm}^{-1}, 1472.21 \mathrm{~cm}^{-1}, 2357.73 \mathrm{~cm}^{-1}, 2846.49 \mathrm{~cm}^{-1}$ and $2913.46 \mathrm{~cm}^{-1}[14]$. 23. The functional group identified in HA are phosphate clusters PO43- on the number of waves $1024 \mathrm{~cm}^{-1}-1092 \mathrm{~cm}^{-1}$, CO32- at a wave number of $1420 \mathrm{~cm}^{-1}-1456$ $\mathrm{cm}^{-1}$, and OH- 3700-3600 $\mathrm{cm}^{-1}, 3550-3500 \mathrm{~cm}^{-1}$, and 3000-1700 $\mathrm{cm}^{-1}\left[20\right.$ and at a wave number of about $3576 \mathrm{~cm}^{-1}$ and 632 $\mathrm{cm}^{-1}[21] 23$.

The cross-linking of the HDPE chain can be observed in the FTIR spectrum (Figure 7. Crosslinking of HDPE chains can be observed on the FTIR spectrum (Fig.7). The C-H vibration FTIR spectrum wavelengths $2914,61 \mathrm{~cm}^{-1} \mathrm{~cm}^{-1}$ was changed to $2913.84 \mathrm{~cm}^{-1} ; 2847,67 \mathrm{~cm}^{-1}$ was changed to $1471,01 \mathrm{~cm}^{-1}$ and $\mathrm{cm}^{-1}$ was changed to $1461,70 \mathrm{~cm}^{-1}$. This is due to and in HDPE and becomes one of the factors that cause hardness value increases after being given $60 \mathrm{kGy}$ radiation. Besides the influence of Gamma, the FTIR spectrum also provides information on the nature of the reaction between HDPE/HA composites. The FTIR spectrum states that the physical HDPE matrix bounds the HA filler. This can be seen at the typical peaks of each HA, and HDPE spectrum, and no new absorption bands are found as new molecules are formed.

\section{4 | CONCLUSION}

HDPE/HA composites with composition HA $0 \%, 5 \%$, and $10 \%$ have been successfully synthesized. Based on the results of research and data processing that has been carried out, in general, with increasing HA composition and radiation dose, the 


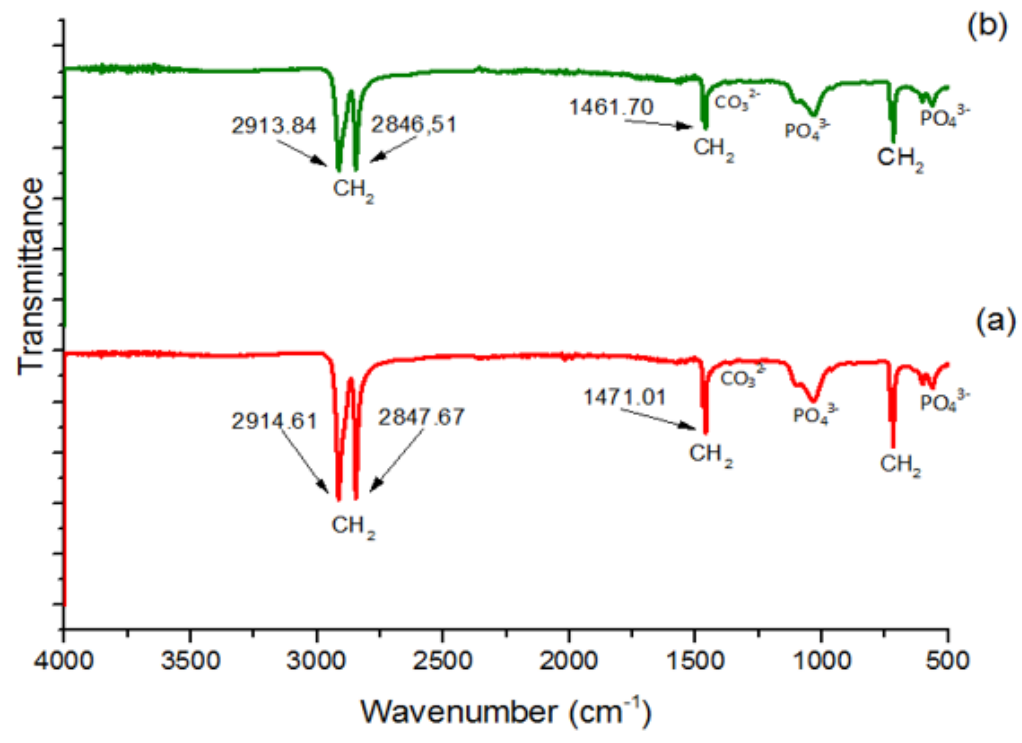

FIGURE 7 Results FTIR characterization HDPE/HA 0kGy.

biocompatibility increases. Furthermore, there were no phase and functional group changes in HDPE/HA composite samples along with the addition of HA composition and radiation dose. The results of hardness test data obtained a good hardness value at $10 \% \mathrm{HA} \mathrm{0kGy}$ with hardness value 39.33 Shore D, 5\% HA 60kGy with hardness value 38.33 Shore D, and $10 \% \mathrm{HA} 60 \mathrm{kGy}$. The hardness value is 40.33 Shore D. This result is suitable if compared with an optimal dose of implant 38-46 Shore D.

\section{5 | ACKNOWLDGEMENT}

This work was supported by The Center for Science and Technology of Advanced Materials (PSTBM), National Nuclear Energy Agency (BATAN)-Serpong.

\section{References}

1. Rack H, Qazi JI. Titanium Alloys for Biomedical Applications. Materials Science and Engineering 2006;26(8):1269-1277.

2. Hollander D, von Walter M, Wirtz T, Sellei R, Schmidt-Rohlfing B, Paar O, et al. Structural Mechanical and in Vitro Characterization of Individually Structured Ti-6Al-4V Produced by Direct Laser Forming. Biomaterials 2006;27(7):955963.

3. Jesus JD, Pedro B, Enori G, Gabriel B, De LSA, Almeida CNH, et al. Microstructure development on sintered Ti/HA biocomposites produced by powder metallurgy. Materials Research 2011;14:384-393.

4. Jarcho M. Calcium Phosphate Ceramics as Hard Tissue Prosthetics. Clinical Orthopaedics and Related Research 1981;157:259-278.

5. Karbhari VM, Wang Q. Influence of Triaxial Braid Denier on Ribbon-Based Fiber Reinforced Dental Composites. Dental materials 2007;23(8):969-976.

6. Cullity BD. Elements of X-Ray Diffraction. USA: Addison Wcsley Pusblishing Company; 1978.

7. Chatwal GR, Anand S. Spectroscopy (Atomic and Molecular). Bombay: Himalaya Publisher; 1985. 
8. Jayachandran V, Kim SK. Effect of Temperature on Isolation and Characterization of Hydroxyapatite from Tuna (Thunnus obesus) Bone. Materials 2010;3(10):4761-4772.

9. Mondal S, Mondal B, Dey A, Mukhopadhyay SS. Studies on Processing and Characterization of Hydroxyapatite Biomaterials from Different Bio Wastes. Journal of Minerals and Materials Characterization and Engineering 2012;11(1):55-67.

10. Wang S, Ge S. The Mechanical Property and Tribological Behavior of UHMWPE: Effect of Molding Pressure. Wear 2007;263(7):949-956.

11. Jafarzadeh Y, Yegani R, Tantekin-Ersolmaz SB. Effect of TiO2 Nanoparticles on Structure and Properties of High Density Polyethylene Membranes Prepared by Thermally Induced Phase Separation Method. Polymers for Advanced Technologies 2015;26(4):392-398.

12. Olmos D, Rodriguez-Gutierrez E, Gonzalez-Benito J. Polymer Structure and Morphology of Low Density Polyethylene Filled with Silica Nanoparticles. Polymer Composites 2012;33(11):1732-1742.

13. Jaggi HS, Kumar Y, Satapathy BK, Ray AR, Patnaik A. Analytical Interpretations of Structural and Mechanical Response of High Density Polyethylene/Hydroxyapatite Bio-Composites. Materials \& Design 2012;36:757-766.

14. Chaudhary AK, Vijayakuma RP. Effect of Chemical Treatment on Biological Degradation of high-Density Polyethylene (HDPE). Environment, Development and Sustainability 2018;22:1093-1104.

15. Away RDY. Pengaruh Penambahan TiO2 pada Hidroksiapatit terhadap Kekuatan Mekanik Hidroksiapatit. PhD thesis, Universitas Andalas; 2014.

16. Sukaryo SG, Arifin NL, Sudaryo S, Sudirman S. Pengaruh Radiasi Gamma terhadap Sifat Mekanik UHMWPE untuk Tibial Tray. Kimia Kemasan 2012;34(2):271-280. http://ejournal.kemenperin.go.id/jkk/article/view/1863

17. Suliwamo A, Sunamr A, Marlijanti I, Sumartri M, Susilawati S. Studi Degradasi Polipropilen (PP) Iradiasi pada Kondisi Lingkungan. In: Prosiding Pertemuan llmiah Sains Materi Jakarta: BATAN; 1997. p. 198-204. http://digilib.batan.go.id/ ppin/katalog/file/1410-2897-1997-1-198.pdf

18. Gulmine J, Janissek PR, Heise HM, Akcelrud L. Polyethylene Characterization by FTIR. Polymer Testing 2002;21(5):557_ 563.

19. Yulindo Y. Migrasi Dioktil Ftalat dan Etilen Glikol ke dalam Stuktur Poliuretan dengan Memanjang Rantai Diamina Aromatik dan Pengaruhnya terhadap Kinerja Material. PhD thesis, Universitas Indonesia; 2008.

20. Stuart BH. Infrared Spectroscopy: Fundamentals and Applications. John Wiley \& Sons, Ltd; 2004. http://www.rfpc.ir/ uploads/Infrared\{_\}Spectroscopy.pdf

21. Chandrasekaran A, Suresh S, Dakshanamoorthy A. Synthesis and Characterization of Nano-hydroxyapatite (n-HAP) using the Wet Chemical Technique. International journal of physical sciences 2013;8(30):1639-1645.

22. Arsad MSM, Lee PM, Hung LK. Synthesis and Characterization of Hydroxyapatite Nanoparticles and $\beta$-TCP Particles. In: 2nd International Conference on Biotechnology and Food Science IACSIT Press; 2011. p. 184-188. http://www.ipcbee. com/vol7/43-ICBFS2011S036.pdf

23. Aydin E. Biodegradable Polymerhydroxyapatite Nanocomposites for Bone Plate Applications. PhD thesis, Middle East Technical University; 2010.

How to cite this article: Gultom P., Wicaksono S.T., Purniawan A., Sudirman S., Sukaryo S.G. (2020), The Effect of Gamma Irradiation on HDPE/HA Composite as Candidate Material Dental Implant, IPTEK The Journal of Technology and Science, $31(1): 25-32$. 